\author{
LESZEK MISIARCZYK \\ WNHiS UKSW, Warszawa
}

\title{
KANONY EUZEBIUSZA Z CEZAREI W EWANGELIARZU ANASTAZJI Z XII WIEKU
}

Euzebiusz z Cezarei, autor słynnej Historii kościelnej powstałej w IV wieku wprowadził do rękopisów ewangelicznych swego rodzaju konkordancję miejsc paralelnych w innych Ewangeliach zwanych canones ${ }^{1}$. W Liście do Karpianusa wyjaśnia, iż wzorował się na Konkordancji ewangelicznej niejakiego Ammoniusza z Aleksandrii, która przedstawiała Ewangelie w czterech paralelnych kolumnach ${ }^{2}$. Ponieważ podział Ammoniusza pozwalał na czytanie ciągiem tylko Ewangelii Mateusza, Euzebiusz udoskonalił go w ten sposób, aby taka lektura była możliwa w przypadku każdej z czterech Ewangelii. Podzielił więc Ewangelie na mniejsze jednostki, numerując je w różny sposób w każdej z nich. I tak Ewangelię Mateusza podzielił na 355 jednostek, Marka na 233, Łukasza na 242 i Jana 232 jednostki, co w sumie dało 1165 jednostek dla wszystkich czterech Ewangelii ${ }^{3}$ Dzisiaj oczywiście bardzo trudno jest odtworzyć cały system podziału Euzebiusza, gdyż nie wiemy dokładnie, z jakiej wersji tekstu greckiego korzystał w IV wieku. Niemniej jednak wygląda na to, że był on dosyć nowatorski jak na tamte czasy.

Po dokonaniu podziału na wspomniane jednostki Euzebiusz przygotował następnie 10 kanonów zawierających listę fragmentów poszczególnych Ewangelii według ustalonego porządku, który przedstawił również we wspomnianym wcześniej Liście do Karpinusa:

kanon I - miejsca wspólne wszystkim czterem Ewangeliom,

kanon II- miejsca wspólne w Ewangeliach synoptycznych Mateusza, Marka i Łukasza, kanon III - miejsca wspólne w Ewangeliach Mateusza, Łukasza i Jana,

kanon IV - miejsca wspólne w Ewangeliach Mateusza, Marka i Jana,

kanon V - miejsca wspólne w Ewangeliach Mateusza i Łukasza,

kanon VI - miejsca wspólne w Ewangeliach Mateusza i Marka,

kanon VII - miejsca wspólne w Ewangeliach Mateusza i Jana,

kanon VIII - miejsca wspólne w Ewangeliach Łukasza i Marka,

kanon IX - miejsca wspólne w Ewangeliach Łukasza i Jana,

1 Por. Euzebiusz Cezarei, Canones Evangeliorum, PG 22,1277-1292; zob także J. Quasten, Patrologia, t. II, Casale Monferrato 1980, s. 338-339.

2 Euzebiusz z Cezarei, Epistula ad Carpianum, PG 22,1275-1278. Tekst Listu zachował się w kilku wersjach językowych: wersję grecką przedrukował H. von Soden, Die schriften des Neuen Testamentes, I, Berlin 1902, s. 388-391; wersję koptyjską: A. Hebbelynck, Les kephalaia et les titoloi des Evangiles, Museon 41 (1928) s. 81120, natomiast armeńska: A, Vardanian, Euthalius' Werke. Untersuchugen und Texte. Anhabg: Brief es Eusebios von Kaisareia an Karpianos, Wien 1930, s. 23-26.

3 W moim studium na temat kanonów Euzebiusza w Biblii Płockiej przytaczam ten podział - por. L. Misiarczyk, Canones Eusebiani w Biblii Płockiej z XII wieku, „Vox Patrum” 30 (2010) t.55, s. 421-441. 
kanon X - miejsca własne w poszczególnych Ewangeliach w porządku następującym: fragmenty tylko u Mateusza, tylko u Marka, tylko u Łukasza i tylko u Jana.

Tak sporządzone tablice wraz z numerami wersetów czy sekcji pozwalały bardzo szybko odszukać ich miejsca paralelne w pozostałych Ewangeliach a także odnaleźć miejsca własne.

System Euzebiusza rozpowszechnił się bardzo szybko w starożytności chrześcijańskiej i przyjął się szeroko nie tylko w rękopisach greckich, ale również syryjskich i łacińskich pod nazwą Canones Eusebiani albo Canones Eusebii. Upowszechnił się jeszcze bardziej, zwłaszcza w chrześcijaństwie zachodnim i w obszarze języka łacińskiego dzięki Hieronimowi, który włączył go do swojej Wulgaty ${ }^{4}$. Z kolei w późniejszych stuleciach, gdy w świecie zachodnim rozpowszechniają się wersje łacińskie Ewangelii oparte zasadniczo właśnie na Wulgacie, kanony Euzebiusza były umieszczane w różnych biblijnych rękopisach średniowiecznych w Europie i w Polsce. Doskonałym przykładem tego procesu jest Biblia Płocka z XII wieku, w której znajdujemy właśnie takie kanony Euzebiusza, co bez wątpienia dowodzi ich szerokiego zastosowania w świecie chrześcijańskim przez wiele następnych stuleci a także geniuszu intuicji samego Euzebiusza ${ }^{5}$. Po publikacji kanonów Euzebiusza z Biblii Płockiej chciałbym w niniejszym opracowaniu przedstawić te zachowane w Ewangeliarzu Anastazji z XII i porównać je ze sobą. Pozwoli to dokładniej prześledzić proces rozpowszechniania się ich w XII wieku w Polsce, a także może być wskazówką pomocną w dokładniejszej datacji powstania samego Ewangeliarza Anstazji.

\section{Ewangeliarz Anastazji}

Dzieje Ewangeliarza Anastazji są ściśle związane z historią chrystianizacji Mazowsza. Choć niewykluczone, że pierwsi misjonarze docierali na tereny Mazowsza już w X czy nawet IX wieku, nie posiadamy jednak żadnych źródeł, które by to potwierdziły. Jak się przyjmuje, papież Grzegorza VII erygował diecezję płocką w 1075 roku $^{6}$, a w drugiej połowie XI wieku pojawiają się już w Płocku pierwsze kodeksy biblijne, czego przykładem jest słynny Codex aureus Pultoviensis pochodzący właśnie z tego okresu. Prawdziwy jednak rozkwit księgozbioru na użytek zarówno miejscowej katedry, jak też zapewne szkoły przykatedralnej, ma miejsce w pierwszej połowie XII wieku za rządów biskupa Aleksandra z Malonne (1129-1156), który sprowadził do Płocka wiele ksiąg a także stworzył miejscowe skryptorium7 ${ }^{7}$ On wzniósł pierwszą bazylikę katedralną z kamienia na Wzgórzu Tumskim w Płocku, która została konsekrowana w 1144 roku i zapewne na użytek liturgii w nowopowstałej katedrze sprowadził do Płocka podczas swoich rządów diecezją słynną Biblię Płocka ${ }^{8}$, Evangelium secundum Marcum, Pericopae evangelicae 9 .

\footnotetext{
4 Hieronim wyjaśnia system Euzebiusza w Liście do papieża Damazego (Epistula ad Damasum). Por. także J. Quasten, Patrologia, vol. II, Casale Monferrato 1980, s. 338.

Por. L. Misiarczyk, Canones Eusebiani w Biblii Płockiej z XII wieku, „Vox Patrum” 30 (2010) t.55, s. 421-441.

Por. T. Żebrowski, Zarys dziejów diecezji płockiej, Płock 1976, s. 13nn; tenże, Kościót (X-XIII wiek), w: A. Gieysztor - H. Samsonowicz (red.), Dzieje Mazowsza do 1526 roku, Warszawa 1994, s. 132- 162.

7 Por. W. Graczyk, Biblioteka katedralna Płocka od średniowiecza do nowożytności, w: tenże (red.), Biblioteka Wyższego Seminarium Duchownego w Płocku, Płock 2003, s. 7-71; W. Graczyk - J. M. Marszalska, Księgi rękopiśmienne i stare druki w zbiorach Biblioteki Wyższego Seminarium Duchownego w Płocku. Z dziejów kultury polskich bibliotek kościelnych w dawnych wiekach, Kraków 2010, s. 25-35.

8 Por. R. Knapiński, Illuminacje romańskiej Biblii Płockiej, Lublin 1992, s. 9-10; W. Graczyk - J. M. Marszalska, Księgi rękopiśmienne i stare druki w zbiorach Biblioteki Wyższego Seminarium Duchownego w Płocku. Z dziejów kultury polskich bibliotek kościelnych $w$ dawnych wiekach, Kraków 2010, s. 79nn.

9 Por. R. Knapiński, Illuminacje romańskiej Biblii Płockiej, s. 9-10.
} 
Jeśli chodzi o nasz Ewangeliarz Anastazji, to jak się przypuszcza, dotarł on do Płocka za czasów Aleksandra z Malonne ${ }^{10}$ lub jego następcy biskupa Wenera (1156-1170), który przywiózłby go z podróży na dwór Fryderyka Barbarossy, dokąd udał się jako przedstawiciel księcia ${ }^{11}$. Nie wiadomo dokładnie od kiedy i dlaczego łączono go z postacią Anastazji, która nie jest bliżej znana badaczom zajmującym się genealogią Piastów ${ }^{12}$. Jan Długosz nazywa takim imieniem Wierzchosławę, córkę Wsiewłoda, księcia nowogrodzkiego poślubioną przez Bolesława Kędzierzawego, trudno jednak określić, czy ta informacja zasługuje na zaufanie. Nie wykluczone, że chodzi o tę samą osobę, która nosiłaby dwa imiona: jedno słowiańskie Wierzchosława a drugie chrzcielne właśnie Anastazja. Prawdopodobnie to jej śmierć stała się przyczyną zamówienia ewangeliarza jako dar-ofiara za zbawienie jej duszy ${ }^{13}$. Nie mamy jednak pewności co do dokładnej daty tej śmierci a ona wiele pomogłaby w datacji samego kodeksu. Podawane są dzisiaj dwie daty: badacz genealogii Piastów O. Balzer przypuszcza, że miała ona miejsce w $1148 \mathrm{roku}^{14}$, inni proponują $1158 \mathrm{rok}^{15}$. Zapewne należał on początkowo do księgozbioru katedry płockiej a później, jak sugeruje T. Mroczko, zostałby przekazany przez Bolesława IV w 1161 roku nowej fundacji kanoników regularnych w Czerwińsku, gdyż dokument z 1808 roku wymienia w spisie jako „księgę z Ewangeliami całą w srebro oprawioną"16. Nie mamy jednak pewności, że chodzi rzeczywiście o Ewangeliarza Anastazji czy też o jakiś inny, podobny kodeks. W 1831 biskup płocki A. M. Prażmowski ofiarował go jako dar dla Towarzystwa Przyjaciół Nauk w Warszawie i zapis o tym przekazie znajdujemy na pierwszej karcie kodeksu. Po upadku powstania listopadowego Ewangeliarz wywieziono do Petersburga i przechowywano w Carskiej Bibliotece Publicznej, co potwierdzają pieczęcie tej biblioteki na 1,2 i ostatniej karcie kodeksu oraz notatka w j. rosyjskim z 1899 roku na ostatniej karcie. Obecnie kodeks znajduje się w Bibliotece Narodowej w Warszawie w zbiorze rękopisów pod numerem katalogowym II 3307.

Kodeks zawiera 66 kart pergaminowych, z których 64 zapisane są tekstem Ewangelii, a 2 dodatkowe zostały umieszczone na początku: pierwsza przekazuje nam zapis darowizny biskupa Prażmowskiego a druga to karta z tekstem genealogii Jezusa, ale wzięta z jakiegoś innego kodeksu i zapisana inną ręką. Kodeks o wymiarach $30,5 \times 20 \mathrm{~cm}$ został zapisany minuskułą karolińską w jednej kolumnie. Zwiera Prephatio św. Hieronima do czterech Ewangelii, następnie Prologus, Argumentum, Capitula, kanony Euzebiusza, Evangelium Matthei, Evangelium Lucae, Commentatio in Johannem Evangelistam oraz Evangelium Johannis.

Oprawa kodeksu, jak przypuszcza Wł. Semkowicz jest oryginalna z XII wieku ${ }^{17}$ i została sporządzona $\mathrm{z}$ drewna dębowego, które następnie zostało pokryte srebrną blachą

\footnotetext{
10 Takiego zdania jest Wł. Semkowicz, Paleografia łacińska, Kraków 1951, s. 137, choć nie badał dokładnie całego kodeksu.

11 Por. C. K. Święcki, Kultura literacka Płocka w średniowieczu, Warszawa-Siedlce 2006, s. 49-53; tenże, Kultura piśmienna w Polsce średniowiecznej X-XII wiek, Warszawa 2010, s. 135-138.

12 Por. O. Balzer, Genealogia Piastów, Kraków 1895, s. 5; K. Askanas, Srebrna okładka „Ewangeliarza księżnej Anastazji”, „Notatki Płockie” 1989, z. 2, s. 9-10; T. Mroczko, Czerwiński romański, Warszawa 1972, s. 50.

13 Por. C. K. Święcki, Kultura literacka Płocka wśredniowieczu, s. 50; tenże, Kultura piśmienna w Polsce średniowiecznej X-XII wiek, s. 136.

14 Por. O. Balzer, Genealogia Piastów, Kraków 1895, s. 5.

15 Por. C. K. Święcki, Kultura literacka Płocka w średniowieczu, s. 50.

16 T. Mroczko, Czerwiński romański, s. 47.

17 Por. Wł. Semkowicz, Paleografia, s 134.
} 
ozdobioną płaskorzeźbami i napisami, co czyni z naszego kodeksu wyjątek w Europie. Zdaniem T. Mroczko podobną oprawą ze srebra posiadają w Europie jedynie dwa kodeksy zachowane do naszych czasów: Ewangeliarz z Namur w Belgii i z Treviso we Włoszech ${ }^{18}$. Przednia część oprawy przedstawia scenę ukrzyżowania ze stojącymi obok Maryją i Janem Ewangelistą oraz klęczącą u stóp krzyża kobietą, jak się przypuszcza właśnie Anastazją. Natomiast w górnych medialonach znajduje się symbol słońca i napis „sol” oraz księżyca „luna”. Tylna okładka przedstawia Chrystusa na tronie z kodeksem w lewej ręce i uniesionymi do góry dwoma palcami prawej ręki oraz litery A i W. W czterech narożnikach umieszczone zostały symbole czterech Ewangelistów: człowiek - Mateusza, orzeł - Jana, lew - Marka i byk - Łukasza. Na okładkach znajdują się elementy sztuki bizantyjskiej i mozańskiej, i to wymieszanie stylów wskazywałoby, że nie pochodzi on z kraju Mozy, ale powstał na miejscu - w Płocku, gdzie od czasów biskupa Aleksandra przebywali skrybowie i mistrzowie sztuki mozańskiej. W przypadku jednak naszego Ewangeliarza połączyliby sztukę mozańską z elementami bizantyńskiej, która docierała na tereny Polski. W każdym razie potrzebna jest dokładniejsza analiza kodeksu przez historyków sztuki.

\section{Kanony Euzebiusza w Ewangeliarzu Anastazji}

Kanony Euzebiusza znajdują się na kartach 6-8 liniowanych inkaustem zapisane wewnątrz łuków z kolumnami zewnętrznymi i środkowymi. Od góry karty 6r znajdujemy napis: Canon I[us] in q[uo] IIII: Math[eu]s, Marcus, Luca[s], Johannes. Chodzi więc o kanon pierwszy, który przedstawia miejsca paralelne w czterech Ewangeliach.

Kanon I: Mateusz, Marek, Łukasz, Jan

\begin{tabular}{|c|c|c|c|}
\hline Mt & Mk & Lk & J \\
\hline VIII & II & VII & X \\
\hline XI & IIII & X & V \\
\hline XI & IIII & X & XI \\
\hline XI & IIII & X & XIIII \\
\hline XI & IIII & X & XXVIIII \\
\hline XIIII & V & XIII & XV \\
\hline XIII & XXVII & XII & XLVI \\
\hline LXX & XXVII & XLV & XLVI \\
\hline XCVIII & XXVII & XLV & XLVI \\
\hline XCVIII & XXVII & XLV & XLVI \\
\hline XCVIII & XX & XXXVII & XXXVIII \\
\hline XCVIII & XCVI & CXVI & CXX \\
\hline XCVIII & XCVI & CXVI & CXI \\
\hline XCVIII & XCVI & CXVI & CXL \\
\hline CXXXIII & XCVI & CXVI & CXLIIII \\
\hline CXLI & XCVI & CXVI & CXXVIII \\
\hline CXLII & XCVI & CXVI & CXXXI \\
\hline CXLVII & XXVII & LXXVI & CIX \\
\hline C[X]LXVI ${ }^{20}$ & L & XIX & LIX \\
\hline CLXVI & LI & XXI & XXXV \\
\hline
\end{tabular}

\begin{tabular}{|c|c|c|c|}
\hline $\mathbf{M t}$ & $\mathbf{M k}$ & $\mathbf{L k}$ & $\mathbf{J}$ \\
\hline CCCII & CLXXVI & CCLXXII & XLII \\
\hline CCCIIII & CLXXXI & CCLXXXV & CLVIII \\
\hline CCCVI & CLXXXI & CCLXXXVII & LXXIX \\
\hline CCCVI & CLXXXI & CCLXXXIX & CLX \\
\hline CCCX & CLXXXIII & CCXC & CLXX \\
\hline CCCXIII & CLXXXIIII & CCXC & CLXII \\
\hline CCCXIIII & CLXXXVII & CC[XCII] & CLXXIIII \\
\hline CCCXIIII & CLXXXVII & CCXCIIII & LXVIII \\
\hline CCCXV & CXCI & CCXCI & CLXII \\
\hline CCCXVIII & CXCIII & CCXCI & CLXVIII \\
\hline CCCXX & CXCV & CCXCI & CLXVII \\
\hline CCCXXVI & CXCVI & CCC[II] & CLXXV \\
\hline CCCXXVI & CXCVI & CCCII & CLXXVI \\
\hline CCCXXVI & CXCIX & CCCX & CLXXVIII \\
\hline CCCXXVIII & CC & CCCXI & CLXXXIIII \\
\hline CCCXXXI & CCIIII & CCC[III $]$ & CLXXXVIII \\
\hline CCCXXXII & CCV & CCCXVIII & CXCIII \\
\hline CCCXXXIII & CCVI & CCCV & CXCVI \\
\hline CCCXXXV & CCIX & CCCXIX & CXCVII \\
\hline CCCXXXVI & CCX & CCCXXI & CXCVIII \\
\hline
\end{tabular}

\footnotetext{
18 Por. T. Mroczko, Czerwiński romański, s. 49-50.

19 Wyraźny błąd kopisty. W kanonach Biblii Płockiej mamy 98, 96, 116 i 144. W konsekwencji każda następna linia również została przesunięta.

20 Kopista pomylił się i początkowo napisał CXL, ale potem przekreślił pierwsze X pisząc dalej CLXVI.
} 


\begin{tabular}{|c|c|c|c|}
\hline $\mathbf{M t}$ & $\mathbf{M k}$ & $\mathbf{L k}$ & $\mathbf{J}$ \\
\hline CCVIIII & LXIV & XCIII & XLIX \\
\hline CCXI & LXXXII & XCIIII & LXIIII \\
\hline CCXX & LXXII & XCIII & XVII \\
\hline CCXX & CXIX & CCXXXIII & C \\
\hline CCXX & CXXI & CCXXXVIII & XXI \\
\hline CCXLIII & CXXI $^{21}$ & CCXXXIX & CXXXV \\
\hline CCXLIIII & CCXXXIX & CCXLII & LXXXVIII \\
\hline CCXLIIII & CCXXXIX & CCLXI ${ }^{23}$ & LXXVII \\
\hline CCLXXIV & CLVI & CCL & CLXVI \\
\hline CCLXXIV & CLVI & CCL & CXLI \\
\hline CCLXXIV & CLVI & CCLX & XX \\
\hline CCLXVI & CLVIII & CCLX & XLVIII \\
\hline CCLXXX & CLXII & CCLX & XCVI \\
\hline CCLXXXIV & CLXV & CCLXIII & XCVIII \\
\hline CCLXXXIV & CLXV & CCLXIX & CXXII \\
\hline CCLXXXIV & CLXV & CCLXVI & LV \\
\hline CCLXXXIV & CLXV & CCLXVI & LXIII \\
\hline CCLXXXIX & CLXX & CCLX[VI] & LXV \\
\hline CCXCI & CLXXII & CCLX??? ${ }^{25}$ & LXVII \\
\hline CCXCIIII & CLXXII & CCLXV & CXXVI \\
\hline $\begin{array}{c}\text { CCXCV. } \\
\text { CCXCV[I] }\end{array}$ & CLXXV & CCLXXIX & CLV \\
\hline CCC & CLXXVI & CCLXXXI & CLXI \\
\hline CCC & CLXXVI & CCLXXXI & LVII \\
\hline
\end{tabular}

\begin{tabular}{|c|c|c|c|}
\hline Mt & Mk & $\mathbf{L k}$ & $\mathbf{J}$ \\
\hline CCCXXXVI & CCXII & CCCXXIIII & $\mathrm{CCI}$ \\
\hline CCCXLIIII & CCXIIII & CCCXVII & $\mathrm{CCXC}[\mathrm{III}]$ \\
\hline CCCXLVIII & CCXV & CCCXIX & CCXCVIII \\
\hline CCCXLIX & CCXVI & CCCXXIX & CCIIII \\
\hline CCCXLI & CCXVII & CCCXXII & CCVI \\
\hline CCCXLII & CCXXIX & CCCXXXIII & CCVIII \\
\hline & CCXXXI & CCCXXXVI & CCIX \\
\hline & CCXXXI & CCCXXXVI & $\mathrm{CC}[\mathrm{X}]$ \\
\hline & & & \\
\hline & & & \\
\hline & & & \\
\hline & & & \\
\hline & & & \\
\hline & & & \\
\hline & & & \\
\hline & & & \\
\hline & & & \\
\hline & & & \\
\hline & & & \\
\hline & & & \\
\hline & & & \\
\hline & & & \\
\hline
\end{tabular}

$\mathrm{Na}$ dole kolumn znajduje się napis: Finit canon in quo IIII.

Na karcie 6v zapisany został kanon II: Canon II in q[u]o III: Matheus, Marc[us], Lucas, który zawiera miejsca paralelne trzech Ewangelii: Mateusza. Marka i Łukasza.

Kanon II: Mateusz, Marek, Łukasz

\begin{tabular}{|c|c|c|}
\hline Mt & Mk & Lk \\
\hline XV & VI & XV \\
\hline XXI & X & XXII \\
\hline XXXI & CII & CLXXXV \\
\hline XXXII & XXXIX & CLXXXIII \\
\hline V & XXXIX & LXXIX \\
\hline LXII & XLI & LV \\
\hline LXII & XIII & IIII \\
\hline LXIII & XIII & XXIII \\
\hline LXVII & XVIII & XXV \\
\hline LXIX & XV & LXXXIII \\
\hline LXXV & XLVII & XXXIX \\
\hline LXXII & XXVI & XXXIX \\
\hline
\end{tabular}

\begin{tabular}{|c|c|c|}
\hline $\mathbf{M t}$ & $\mathbf{M k}$ & $\mathbf{L k}$ \\
\hline CLXXIX & CVI & CXCVII \\
\hline CXC & CVII & CXCV \\
\hline CXCII & CVII & CCXVI \\
\hline CXC & CVIII & CCXXI \\
\hline CXCIII & CVIII & CCXVIII \\
\hline CXCIII & CIX & CCLII \\
\hline CXCIII & CX & CCXVIII \\
\hline CXCIII & CXI & CCXX \\
\hline CXCV & CXII & CCXXI \\
\hline CXCVIII & CXIIII & CCXXVIII \\
\hline CXCVIIII & CXV & CCXXII \\
\hline CCI & CXVI & CCLI \\
\hline
\end{tabular}

21 W Biblii Płockiej 122.

22 W Biblii Plockiej 239.

23 W Biblii Plockiej 241.

24 W Biblii Płockiej pojawił się w tym miejscu dziwny zapis CXLXVI, a dzięki obecnemu kanonowi widzimy wyraźnie, że był to błąd kopisty i również w tamtym przypadku chodziło o tę samą liczbę.

25 Ostatnia liczba nieczytelna. 


\begin{tabular}{|c|c|c|}
\hline Mt & Mk & Lk \\
\hline LXXII & XXII & CLXXXVI \\
\hline LXXIII & XXII & XLVI \\
\hline LXXIII & XXIII & LXXV \\
\hline LXXVII & XLVIII & CLXIX \\
\hline LXXVIII & LII & LXXXVI \\
\hline LXXX & XXIX & XLVI \\
\hline LXXXI & XXX & LXXXV \\
\hline LXXXII & LIII & $\mathrm{CX}$ \\
\hline LXXXIII & LIII & LXXXVIII \\
\hline LXXXIII & LV & CXIII \\
\hline LXXXV & LV & CXIIII \\
\hline LXXXV & CXLI & LXXXIX \\
\hline LXXXVIII & $\mathrm{XL}$ & CXLVIII \\
\hline LXXXVIII & LXXXVI & CCLI \\
\hline XCII & LXXXVI & LXXX \\
\hline XCIIII & $\mathrm{L}$ & XCVII \\
\hline XCIIII & XXVII & CXLVI \\
\hline CXII & XXV & LXX \\
\hline CXIIII & XXXIII & XLI \\
\hline CXVI & $\mathrm{XXX[III]}$ & XLII \\
\hline CXXI & XXXIII & CXXVII \\
\hline CXXI & XXXV & CXXIX \\
\hline CXXIII & XXXVI & CXXVI \\
\hline CXXXIII & XXXVIII & LXXVI \\
\hline CXXXV & XLIIII & LXVIII \\
\hline CXXXVII & LVII & CLXVI \\
\hline CXLIII & LIX & $\mathrm{XC}$ \\
\hline CXLIIII & LXI & XII \\
\hline CXLIX & LXIX & XLIII \\
\hline CXLIX & LXIX & XXXV \\
\hline CLIII & LXXXIII & XXVI \\
\hline CLXIIII & LXXXIII & CXLIIII \\
\hline CLXVIII & LXXXV & $\mathrm{XCV}$ \\
\hline CLXVIII & LXXXVII & CCVI \\
\hline CLXX & $\mathrm{XCI}$ & XCVI \\
\hline CLXXII & XCIII & XCVIII \\
\hline CLXXIIII & $\mathrm{XC}[\mathrm{V}]$ & XCIX \\
\hline CLXXVI & $\mathrm{XCV}$ & $\mathrm{C}$ \\
\hline CLXXVIII & XCVIII & $\mathrm{CII}$ \\
\hline CLXXVIII & $\mathrm{CV}$ & CVII \\
\hline
\end{tabular}

\begin{tabular}{|c|c|c|}
\hline Mt & Mk & $\mathbf{L k}$ \\
\hline CCIIII & CXIX & CCXLIII \\
\hline $\mathrm{CCV}$ & CXXVII & CCXLV \\
\hline CCVI & CXIX & CCXLIIII \\
\hline CCVIII & CXXXIIII & CCXXXVII \\
\hline CCXV & CXXXV & CCXLVIII \\
\hline \multicolumn{3}{|l|}{ CCXVI } \\
\hline CCXXIX & CXXXV & CCXL[IX] \\
\hline CCXLII & CXXXVI & CCIX \\
\hline CCXLII & CXXXVII & CLIII \\
\hline CCXLIII & CXXXVIII & CLIIII \\
\hline CCXLVIII & CXLIII & CLV \\
\hline CCXLIX & CXLIII & CIIII \\
\hline CCLI & CXLVI & CLVII \\
\hline CCLIII & $\mathrm{CL}$ & CLVIII \\
\hline CCLVIII & CLI & CLVIII \\
\hline CCLIX & CLV & CLVI \\
\hline CCLXIIII & CLIIII & CCXXVIII \\
\hline CCL??? & CLI[I] & CCXXX \\
\hline CCLXXI & CXL & CCXLIII \\
\hline CCLXXIX & CXLIIII & CCXLIX \\
\hline CCLXXXI & CLXVI & CCLXV \\
\hline CCLXXXV & CLXVI & CCLXVII \\
\hline CCLXXXV & CLXVII & CCLXXX \\
\hline CCXXVI & CLXVII & CCLXXXIII[I] \\
\hline CCXXVI & CLXXXII & CCLXXXVI \\
\hline CCCI & CLXXXIII & $\mathrm{CCCV}$ \\
\hline CCCVIII & CXCIII & CCCXX[IX] \\
\hline CCCXII & CXCVII & CCCXCV \\
\hline CCCXVI & CXCVIII & $\mathrm{CCC}[\mathrm{IX}]$ \\
\hline CCCXVII & CCII & CCCXXII \\
\hline CCCXXII & CCXVIII & CCCXXV \\
\hline CCCXXXVIII & CCXIX & CCCXXXVII \\
\hline CCCXXXIX & CCXX & CCCXXIII \\
\hline CCCXL & CCXXII & CCCXXVIII \\
\hline CCCXLII & CCXXIIII & CCCXXX \\
\hline CCCXLIIII & CCXXV & CCCXXXVII \\
\hline CCCXLVI & CCXXXII & CCCXXXVIII \\
\hline CCCLIII & CCXXXIII & \\
\hline CCCLIIII & & \\
\hline
\end{tabular}

Na dole napis: Finit canon in quo tres, choć na następnej karcie 7r mamy kontynuację tego samego kanonu II.

Na karcie 7r natomiast zostało umieszczonych kilka kanonów razem od III do VI. Od góry w lewej części karty mamy kontynuację kanonu II, w środkowej lewej części karty kanon III a na dole również lewej części karty kanon IIII. Natomiast poczynając od góry prawej strony karty, znajdujemy kanon V i obok niego VI. W środkowej częśći kary 7r czytamy: Canon III[us] in q[uo] III: Math[eu]s, Luca[s], Ioh[ann]es. Kanon ten został przedstawiony w trzech kolumnach oddzielnych od siebie pilastrami, ale bez arkad u góry. 
Kanon III: Mateusz, Łukasz, Jan

\begin{tabular}{|c|c|c|}
\hline Mt & Lk & J \\
\hline I & XIIII & I \\
\hline I & XIIII & III \\
\hline I & VI & V \\
\hline VII & LXIII & II \\
\hline VII & LXV & XXV \\
\hline LIX & LVIII & CXVI \\
\hline XLIII & LVIII & CXXXVII \\
\hline XC & CCXI & CXVIII \\
\hline XC & C[C]XIX & CXXXIX \\
\hline XCVII & CXIX & CV \\
\hline CXI & CXIX & CXLVIII \\
\hline
\end{tabular}

\begin{tabular}{|c|c|c|}
\hline Mt & Lk & J \\
\hline CXI & CXIX & XXX \\
\hline CXI & CXIX & CXIIII \\
\hline CXII & CXIX & LXXXVI \\
\hline CXII & CXIX & XLIIII \\
\hline CXII & CXIX & LXI \\
\hline CXII & CXIX & VIII \\
\hline CXII & CXIX & LXXVI \\
\hline CXII & CXIX & XC \\
\hline CXII & CXIX & CLIIII \\
\hline CXII & CXIX & CXLIII \\
\hline CXLVI & CL & CXLVII \\
\hline
\end{tabular}

Brakuje jakiegokolwiek napisu zamykającego kanon III, a poniżej pojawia się kanon IIII: Canon IIII in q[uo] III: Math[eu]s, Marcus, Iohannes.

Kanon IIII: Mateusz, Marek, Jan

\begin{tabular}{|c|c|c|}
\hline Mt & Mk & J \\
\hline XVIII & VIII & XXVI \\
\hline CXVII & XXVI & XCIII \\
\hline CXVII & XXVI & XCV \\
\hline CL & LXVII & LI \\
\hline CLXI & LXXVII & XXIII \\
\hline CLXI & LXXVII & CX[X]I \\
\hline CCIIII & CXV & CLI \\
\hline CCIII & CXV & CVI \\
\hline CCXVI & CXV & LXX \\
\hline CCXVI & CXV & CIII \\
\hline
\end{tabular}

\begin{tabular}{|c|c|c|}
\hline $\mathbf{M t}$ & $\mathbf{M k}$ & $\mathbf{J}$ \\
\hline CCXVI & CLIX & CXLIIII \\
\hline CCXVI & C[?]LXI & CLXXX \\
\hline CCLXXVII & CLX & CXXII \\
\hline CCLXXVII & CLXIX & CLXXXIII \\
\hline CCCXXI & CLXXIIII & CLXXX[V] \\
\hline CCCXXIIII & CCLXXXVIII & CLXXXVII \\
\hline CCCXXIX & CCIII & CCIII \\
\hline CCCXXIX & CCVII & \\
\hline CCCXXXIIII & CCVII & \\
\hline & CCXI & \\
\hline
\end{tabular}

Brakuje pod kanonem typowego wpisu zamykającego.

$\mathrm{Na}$ tej samej karcie 7r z prawej jej strony mamy kanon V i VI. Górna część karty jest bardzo zabrudzona i trudna do odczytania. W kolumnie lewej czytamy: Canon V in q[uo] II: Math[eu]s, Luca[s].

\begin{tabular}{|c|c|}
\hline Mt & tk \\
\hline III & II \\
\hline X & VIII \\
\hline XII & XI \\
\hline XXVI & XVI \\
\hline XXV & XLVI \\
\hline XXVI & XLVII \\
\hline XXVIII & XLVIII \\
\hline XL & XL[VII \\
\hline XLI & CXCII \\
\hline XLIIII & CLXXII \\
\hline XLVI & LIII \\
\hline XLVII & LII \\
\hline XLVIII & LV \\
\hline XLIX & CXXIII \\
\hline
\end{tabular}

Kanon V: Mateusz i Łukasz

\begin{tabular}{|c|c|}
\hline Mt & Lk \\
\hline CIIII & LXVI \\
\hline CV & CV \\
\hline CVII & CVIII \\
\hline CVIII & CXI \\
\hline CX & CXIX \\
\hline CXVI & CLXV \\
\hline CXVIII & XLX \\
\hline CXXV & CLXXII \\
\hline CXXVII & CLXXXIIII \\
\hline CXXVIII & LXX[IX] \\
\hline CXXIX & LXXX \\
\hline CXXXII & CXX[X]II \\
\hline CXXXVIII & CXV \\
\hline CLVII & CXIX \\
\hline
\end{tabular}

\begin{tabular}{|c|c|}
\hline $\mathbf{M t}$ & $\mathbf{L k}$ \\
\hline CCXXXIII & CXXXVI \\
\hline CCXXXVI & CXXXV \\
\hline CCXXXVII & CXXXVIII \\
\hline CCXXXVIII & CXL \\
\hline CCXL & CXL \\
\hline CCXLI & CLXXXV \\
\hline CCXLV & CCII \\
\hline CCXLVI & CCV \\
\hline CCLXXVI & CCXIII \\
\hline CCLXXI & CCVII \\
\hline CCLXXII & CCXII \\
\hline CCLVV & CCLVII \\
\hline CCLXVI & CLV \\
\hline CCLXVII & CLVIII \\
\hline
\end{tabular}




\begin{tabular}{|c|c|}
\hline Mt & Lk \\
\hline LI & CLIII \\
\hline LIII & CXXXIIII \\
\hline LIII & CXCI \\
\hline LV & CL \\
\hline LVII & LIX \\
\hline LX & CXXV \\
\hline LXI & LIIII \\
\hline CV & CLXX \\
\hline LVI & CLXI \\
\hline XCV & CLX \\
\hline CCCVI & CLXXI \\
\hline CCCVI & LXXIIII \\
\hline CII & CLXXII \\
\hline
\end{tabular}

\begin{tabular}{|c|c|}
\hline Mt & Lk \\
\hline CLVIII & CLXV \\
\hline CLXI & CLXXVII \\
\hline CLXX & CXXVI \\
\hline CLXXXII & LXII \\
\hline CLXXXII & CLXXVIII \\
\hline CLXXXII & CXXXII \\
\hline CLXXXVI & CXXX \\
\hline CXCVII & CXXXI \\
\hline CXIII & CXC \\
\hline CXXI & CLXVIII \\
\hline CCXXVIII & LVII \\
\hline CXXXI & CCXVI \\
\hline CCXXXII & CCXLI \\
\hline
\end{tabular}

\begin{tabular}{|c|c|}
\hline $\mathbf{M t}$ & $\mathbf{L k}$ \\
\hline CCLXX & CCXXIX \\
\hline CCLXXII & CCXXXI \\
\hline & \\
\hline & \\
\hline & \\
\hline & \\
\hline & \\
\hline & \\
\hline & \\
\hline & \\
\hline & \\
\hline & \\
\hline & \\
\hline &
\end{tabular}

Po kolumnami znajduje się napis: Finit canon $V$.

Z kolei od zewnętrznej strony karty 7r mamy kanon VI. Górna część pergaminu jest tak bardzo zabrudzona, iż praktycznie niemożliwe jest odczytanie tytułu. Można się tylko domyślać, że jest tam napis: Canon in q[uo] II: Math[eu]s, Marcu[s]. Natomiast nie ma wątpliwości, że chodzi o kanon VI, gdyż pod kolumną znajdujemy napis: Finit canon VI.

Kanon VI: Mateusz i Marek

\begin{tabular}{|c|c|}
\hline Mt & Mk \\
\hline IX & III \\
\hline$[X V I]$ & VII \\
\hline$[X X]$ & {$[I X]$} \\
\hline$[X X I I]$ & XI \\
\hline$[$ XCIIII $]$ & CXXVI \\
\hline LXXVII & LXIII \\
\hline LXXXVII & CXXXIX \\
\hline C & XXVIII \\
\hline CXXXIX & XLV \\
\hline CXLV & LX \\
\hline CXLVIII & L[XV] \\
\hline CLII & LXIX \\
\hline CLIIII & LXXI \\
\hline CLVII & LXXII \\
\hline CLVIII & LXXX \\
\hline CLX & LXXXIIII \\
\hline CLXIII & LXXXIX \\
\hline
\end{tabular}

\begin{tabular}{|c|c|}
\hline Mt & Mk \\
\hline CLXV & C \\
\hline CLIX & CIII \\
\hline CLXXXIIII & CXIII \\
\hline CLXXX & CXX \\
\hline CLXXXIX & CXXIIII \\
\hline CCII & CXXXI \\
\hline CCXLIII & CXL \\
\hline CCXV & CXLII \\
\hline CCXXV & CXLV \\
\hline CCXLVI & CXLVIII \\
\hline CCXLVI & CXLIX \\
\hline CCL & CLII \\
\hline CCLII & CLIII \\
\hline CCLIIII & CLVII \\
\hline CCLX & CLXXIII \\
\hline CCLXIII & CLXX[VII] \\
\hline CCLXV & CLXIX \\
\hline
\end{tabular}

\begin{tabular}{|c|c|}
\hline $\mathbf{M t}$ & $\mathbf{M k}$ \\
\hline CCLXXXII & CLXXI \\
\hline CCLXXXVI & CLXXXIII \\
\hline CCLXXXVIII & CLXXXIX \\
\hline CCXX & CLXXXV \\
\hline CCXC & CLXXXV \\
\hline CCXCII & CXC \\
\hline CCXCVIII & CXCII \\
\hline CCCV & CCVIII \\
\hline CCCIX & CCXVII \\
\hline CCCXI & CCXXI \\
\hline CCCXXX & CCXXVI \\
\hline CCCXXXVII & CCXX[IX] \\
\hline CCCXLI & \\
\hline CCCXLVII & \\
\hline CCCL & \\
\hline & \\
\hline & \\
\hline
\end{tabular}

Pod tabelą napis: Finit canon VI.

Na karcie 7v mamy powtórzone te same kanony, co na karcie 7r, czyli kontynuację kanonu II, cały kanon III, IIII, V i VI. Trudno jednak rozstrzygnąć motywy tego powtórzenia.

$\mathrm{Na}$ karcie 8r w lewym górnym rogu mamy napis: Canon VI[us] in quo duo: Math[eu] $s$, Joh[anne]s, ale jest to wyraźny błąd kopisty, gdyż kanon VI był już wcześnie a także dlatego, że na jego zakończenie sam napisał: Finit canon VII[us]. Nie ma już tutaj kolumn a jedynie u góry dwa proste łuki. 
Kanon VII: Mateusz i Jan

\begin{tabular}{|c|c|}
\hline Mt & J \\
\hline V & LXXXIII \\
\hline XVIII & LXIX \\
\hline XIX & XXII \\
\hline
\end{tabular}

\begin{tabular}{|c|c|}
\hline Mt & J \\
\hline XXX & XXXIIII \\
\hline CXX & LXXXI \\
\hline & \\
\hline
\end{tabular}

\begin{tabular}{|c|c|}
\hline Mt & J \\
\hline CLXXV & CXV \\
\hline CVII & CI \\
\hline & \\
\hline
\end{tabular}

Poniżej napis: Finit canon VII[us].

Z lewej strony tej samej karty jest kanon VIII: Canon VIII[us] in quo duo Lucas, Marcus.

Kanon VIII: Łukasz i Marek

\begin{tabular}{|c|c|}
\hline Lk & Mk \\
\hline XXIII & XII \\
\hline XXV & XIIII \\
\hline XXVII & XVII \\
\hline XXVII & XXVIII \\
\hline XXVIII & XXVII \\
\hline
\end{tabular}

\begin{tabular}{|c|c|}
\hline $\mathbf{L k}$ & $\mathbf{M k}$ \\
\hline LXXXII & XLIX \\
\hline LXXXIX & LVI \\
\hline XCI & LXI \\
\hline C & LXXV \\
\hline CII & XVII \\
\hline
\end{tabular}

\begin{tabular}{|c|c|}
\hline $\mathbf{L k}$ & $\mathbf{M k}$ \\
\hline CCXLVII & CLXXXVI \\
\hline CCLXXVII & CCXVI \\
\hline CCCXXXV & CCXXX \\
\hline CCCXL & CCXXXIIII \\
\hline & \\
\hline
\end{tabular}

Pod kanonem napis: Finit canon VIII[us]. Warto zauważyć, że kanon VIII jest pierwszym, który zgadza się całkowicie z kanonem VIII zachowanym w Biblii Płockiej, podczas gdy inne, choć bardzo podobne, zawierają błędy w poszczególnych kolumnach.

Na tej samej karcie 8r zapisany został kanon IX: Canon IX in q[uo] duo: Lucas, Iohannes.

\begin{tabular}{|c|c|}
\hline $\mathbf{L k}$ & $\mathbf{J}$ \\
\hline XXX & CCXIX \\
\hline XXX & CCXXIII \\
\hline CCLXXII & CCXIII \\
\hline CCLXXIIII & CCCXXIIII \\
\hline CCLXXIII & CCXIX \\
\hline CCLXXIII & CCXXVII \\
\hline CCCIII & CCXXXI \\
\hline
\end{tabular}

Kanon IX: Łukasz i Jan

\begin{tabular}{|c|c|}
\hline $\mathbf{L k}$ & $\mathbf{J}$ \\
\hline CCCVII & CXC \\
\hline CCCXII & CXC \\
\hline CCCIII & CXC \\
\hline CCCVII & CLXXXVI \\
\hline CCCXII & CLXXXVI \\
\hline CCCXL & CLXXII \\
\hline CCCXL & CLXXXII \\
\hline
\end{tabular}

\begin{tabular}{|c|c|}
\hline $\mathbf{L k}$ & $\mathbf{J}$ \\
\hline CCCXLI & CLXXXII \\
\hline CCCXLI & CCXIII \\
\hline & CCXXI \\
\hline & CCXXV \\
\hline & \\
\hline & \\
\hline & \\
\hline &
\end{tabular}

Pod tablicą jest napis: Finit canon IX[us].

Z prawej strony karty 8r znajduje się kanon X dotyczący miejsc własnych w Ewangelii Mateusza i Marka. Od góry mamy tytuł: Canon X[us] in quo Matheus.

Kanon X: Miejsca własne u Mateusza

\begin{tabular}{|c|}
\hline Mt \\
\hline I \\
\hline IIII \\
\hline VI \\
\hline XIII \\
\hline XXIIII \\
\hline XXVI \\
\hline XXIX \\
\hline XXXIIII \\
\hline
\end{tabular}

\begin{tabular}{|c|}
\hline Mt \\
\hline LVII \\
\hline LXXV \\
\hline LXXXV \\
\hline LXXXIX \\
\hline XCI \\
\hline XCIX \\
\hline CI \\
\hline CVI \\
\hline
\end{tabular}

\begin{tabular}{|c|}
\hline Mt \\
\hline CXVIII \\
\hline CXXIIII \\
\hline CXXVI \\
\hline CXXVI \\
\hline CXL \\
\hline CXLI \\
\hline CLV \\
\hline CLXVII \\
\hline
\end{tabular}

\begin{tabular}{|c|}
\hline Mt \\
\hline CLXXXIIII \\
\hline nieczytelne \\
\hline CXC??? \\
\hline CC \\
\hline CCXX \\
\hline CCXII \\
\hline CCVIII \\
\hline CC \\
\hline
\end{tabular}

\begin{tabular}{|c|}
\hline Mt \\
\hline CCXXXV \\
\hline CCXLIX \\
\hline CCLXXIII \\
\hline CCLXXIII \\
\hline CC[III] \\
\hline CCCXIX \\
\hline CCCXXIIII \\
\hline CCCXVII \\
\hline
\end{tabular}




\begin{tabular}{|c|}
\hline Mt \\
\hline XXXIIII \\
\hline XXXV \\
\hline XXXVII \\
\hline XXXIX \\
\hline XLII \\
\hline XLV \\
\hline LII \\
\hline
\end{tabular}

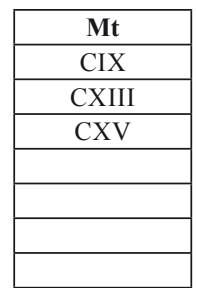

\begin{tabular}{|c|}
\hline Mt \\
\hline CLXXVI \\
\hline CLXXVII \\
\hline CLXXXI \\
\hline \\
\hline \\
\hline \\
\hline \\
\end{tabular}

\begin{tabular}{|c|}
\hline Mt \\
\hline CCXXII \\
\hline CCXXXVII \\
\hline CCXXXIII \\
\hline \\
\hline \\
\hline \\
\hline
\end{tabular}

\begin{tabular}{|c|}
\hline $\mathbf{M t}$ \\
\hline CCCXLV \\
\hline CCCLI \\
\hline CCCLV \\
\hline \\
\hline \\
\hline \\
\hline
\end{tabular}

Pod kanonem mamy napis: Finit canon decimus. Ponieważ kanon X stanowią według Euzebiusza miejsca własne czterech Ewangelii, więc będzie ich wszystkich cztery.

Z prawej strony karty 8r. znajduje się kanon X dotyczący miejsc własnych w Ewangelii Marka: Canon X[us] in quo Marcus.

Kanon X: Miejsca własne u Marka

\begin{tabular}{|c|}
\hline Mk \\
\hline XIX \\
\hline XXI \\
\hline XLIII \\
\hline XLIII \\
\hline
\end{tabular}

\begin{tabular}{|c|}
\hline Mk \\
\hline LVIII \\
\hline LXII \\
\hline LXX \\
\hline LXXIIII \\
\hline
\end{tabular}

\begin{tabular}{|c|}
\hline Mk \\
\hline LXXXI \\
\hline LXXXVII \\
\hline XC \\
\hline XCII \\
\hline
\end{tabular}

\begin{tabular}{|c|}
\hline $\mathbf{M k}$ \\
\hline XCIII \\
\hline CI \\
\hline CIIII \\
\hline CXXIII \\
\hline
\end{tabular}

\begin{tabular}{|c|}
\hline $\mathbf{M k}$ \\
\hline CXXXI \\
\hline CLXXXVI \\
\hline CCXIII \\
\hline CCXXXV \\
\hline
\end{tabular}

Pod kolumną tekstu jest napis: Finit canon decimus.

Natomiast na karcie 8v znajduje się kanon X dotyczący miejsc własnych w Ewangelii Łukasza i Jana. Z lewej strony karty mamy kanon Łukasza: Canon X[us] in quo Lucas.

Kanon X: Miejsca własne u Łukasza

\begin{tabular}{|c|}
\hline Lk \\
\hline I \\
\hline III \\
\hline V \\
\hline IX \\
\hline XVIII \\
\hline XX \\
\hline XXII \\
\hline XXIX \\
\hline XXXI \\
\hline L \\
\hline LI \\
\hline LXVII \\
\hline LXVIII \\
\hline LXXII \\
\hline LXXV \\
\hline
\end{tabular}

\begin{tabular}{|c|}
\hline \multicolumn{1}{|l|}{} \\
\hline CIIII \\
\hline CVI \\
\hline CVII \\
\hline CXIII \\
\hline CXVII \\
\hline CXXII \\
\hline CXXIII \\
\hline CXXXI \\
\hline CXLIII \\
\hline CXLVIII \\
\hline CLI \\
\hline CLIIII \\
\hline CLVIII \\
\hline CLXIIII \\
\hline CLXVI \\
\hline
\end{tabular}

\begin{tabular}{|c|}
\hline Lk \\
\hline CLXXIIII \\
\hline CLXXVI \\
\hline CLXVIII \\
\hline CLXXX \\
\hline CLXXXI \\
\hline CLXXXIX \\
\hline CLXIIII \\
\hline CXC \\
\hline CXCII \\
\hline CXCVI \\
\hline CXCI \\
\hline CXCIII \\
\hline CCVIII \\
\hline CCX \\
\hline CCXIIII \\
\hline
\end{tabular}

\begin{tabular}{|c|}
\hline $\mathbf{L k}$ \\
\hline CCXXIII \\
\hline CCXXV \\
\hline CCXXVII \\
\hline CCXXXVI \\
\hline CCLII \\
\hline CCLVI \\
\hline CCLIX \\
\hline CCLXIIII \\
\hline CCLXI \\
\hline CCLXXIII \\
\hline CCLXXVI \\
\hline CCLXVIII \\
\hline CCLXXXIII \\
\hline CCLXXXVIII \\
\hline CCXCVI \\
\hline
\end{tabular}

\begin{tabular}{|c|}
\hline $\mathbf{L k}$ \\
\hline CCXCVIII \\
\hline CCCI \\
\hline CCCIIII \\
\hline CCCVI \\
\hline CCCXX \\
\hline CCCXVI \\
\hline CCCXX \\
\hline CCCXXVI \\
\hline CCCXXXI \\
\hline CCCXXXIII \\
\hline CCCXXXVIII \\
\hline CCCXLIIII \\
\hline \\
\hline \\
\hline \\
\hline
\end{tabular}

Pod tabelą pojawia się końcowy napis: Finit Luce p[ro]p[ri]etas.

Na tej same karcie po prawej stronie znajdujemy kanon X dotyczący Ewangelii Jana: Canon X[us] in quo Iohannes. 
Kanon X: Miejsca własne u Jana

\begin{tabular}{|c|}
\hline J \\
\hline IIII \\
\hline VII \\
\hline IX \\
\hline XI \\
\hline XIII \\
\hline XVI \\
\hline XVIII \\
\hline XXII \\
\hline XXIIII \\
\hline XXVII \\
\hline XXIX \\
\hline XXXIX \\
\hline XXXIII \\
\hline XXXVI \\
\hline XXXIX \\
\hline XL \\
\hline XLIII \\
\hline XLV \\
\hline L \\
\hline LII \\
\hline
\end{tabular}

\begin{tabular}{|c|}
\hline J \\
\hline LIIII \\
\hline LVI \\
\hline LVII \\
\hline LX \\
\hline LXII \\
\hline LXIII \\
\hline LXV \\
\hline LXVIII \\
\hline LXXI \\
\hline LXXIII \\
\hline LXXV \\
\hline LXXVIII \\
\hline LXXX \\
\hline LXXXI \\
\hline LXXXIIII \\
\hline LXXXVI \\
\hline LXXXIX \\
\hline XCI \\
\hline XCIII \\
\hline XCVII \\
\hline
\end{tabular}

\begin{tabular}{|c|}
\hline $\mathbf{J}$ \\
\hline XCIX \\
\hline CII \\
\hline CIIII \\
\hline CVI \\
\hline CVIII \\
\hline CX \\
\hline CXII \\
\hline CXV \\
\hline CXVI \\
\hline CXVIII \\
\hline CXXV \\
\hline CXXVII \\
\hline CXXX \\
\hline CXXXII \\
\hline CXXXIIII \\
\hline CXXXVI \\
\hline CXXXVIII \\
\hline CXL \\
\hline CXLIIII \\
\hline CXLV \\
\hline
\end{tabular}

\begin{tabular}{|c|}
\hline J \\
\hline CXLVII \\
\hline CXLIX \\
\hline CLI \\
\hline CLIII \\
\hline CLV \\
\hline CLVI \\
\hline CLIX \\
\hline CLXVIII \\
\hline CLXV \\
\hline CLXVII \\
\hline CLXIX \\
\hline CLXXI \\
\hline CLXXIII \\
\hline CLXXVII \\
\hline CLXXIX \\
\hline CLXXXI \\
\hline CXXXIX \\
\hline CXCI \\
\hline CXCIII \\
\hline CXCV \\
\hline
\end{tabular}

\begin{tabular}{|c|}
\hline $\mathbf{J}$ \\
\hline CC \\
\hline CCII \\
\hline CCV \\
\hline CCVII \\
\hline CCX \\
\hline CCXII \\
\hline CCXIII \\
\hline CCXVI \\
\hline CCXVIII \\
\hline CCXX \\
\hline CCXXI \\
\hline CCXXIII \\
\hline CCXXVI \\
\hline CCXXVII \\
\hline CCXXXX \\
\hline CCCXXXII \\
\hline \\
\hline \\
\hline \\
\hline
\end{tabular}

Pod kolumną widnieje napis: Finit Ioh[ann]is p[ro]prietas.

Trudno oczywiście jedynie na bazie Ewangeliarza Anastazji i Biblii Płockiej przedstawić jakieś ostateczne wnioski na temat kanonów Euzebiusza w średniowiecznej Polsce, gdyż wymaga do badań porównawczych z innymi kodeksami biblijnymi z tego okresu, ale postaram się przedstawić poniżej pewne uwagi ogólne.

Na początku warto zaznaczyć, że Kanony Euzebiusza z Ewangeliarza Anastazji po raz pierwszy ukazują się drukiem. Odpowiedź natomiast na pytanie o pochodzenie owych kanonów zarówno z Biblii Płockiej jak też Ewangeliarza Anastazji uzależniona jest ściśle od odpowiedzi na pytanie o pochodzenie samych kodeksów. Przyjmuje się, że zostały one przywiezione do Płocka za czasów biskupa Aleksandra z Malonne (1129-1156) albo biskupa Wernera (1156-1170), ale dokładniejsze badania kodykologiczne, paleograficzne ani pergaminologiczne nie zostały niestety nad tymi kodeksami jak dotychczas przeprowadzone. Ks. R. Knapiński przebadał Biblię Płocka od strony iluminacji, dochodząc do wniosku, że taka ilość profesjonalnych zdobień kodeksu oraz ślady przynajmniej kilku zdobników, wskazuje na to, iż kodeks nie mógł powstać całkowicie na miejscu w Płocku, gdyż w XII wieku nie było tutaj aż tak dużego i profesjonalnego skryptorium ${ }^{26}$. Co najwyżej na miejscu mogły zostać dodane niektóre miniatury, ale całość została pewnie wykonana w kraju Mozy na zamówienie biskupa Aleksandra z Malonne. Jeśli tak, to można by przypuszczać, że również kanony Euzebiusza powstały w kraju Mozy i zostały wraz z kodeksem przywiezione do Płocka. Nie jest to jednak wcale oczywiste, gdyż kanony Euzebiusza w Biblii Płockiej zostały spisane na oddzielnych kartach i dołączone do całego kodeksu. Powstały więc one później, prawdopodobnie w lokalnym skryptorium płockim i zostałaby dołączone do kodeksu w innym czasie. Możliwe, że w średniowieczu kanony Euzebiusza były spisywane na oddzielnych kartach pergaminowych i doszywane do kodeksów.

26 Por. R. Knapiński, Illuminacje romańskiej Biblii Płockiej, Lublin 1992. 
Wtedy również kanony z Biblii Płockiej mogłyby powstać w kraju Mozy i zostać dołączone do kodeksu później. Taka jednak hipoteza jest mało prawdopodobna, gdyż właśnie w Ewangeliarzu Anastazji kanony Euzebiusza pojawiają się na pierwszych kartach kodeksu stanowiących jego integralną cześć. Wszystko wskazuje na to, że zostały spisane wraz z całym kodeksem.

Analiza porównawcza między kanonami Euzebiusza z Biblii Płockiej a tymi z Ewangeliarza Anastazji pozwala stwierdzić, że są to te same kanony. Różnice, jakie między nimi się pojawiają, wynikają z błędów kopisty, który gdy pomylił się raz czy drugi w jednej lub drugiej kolumnie, sprawiał, że automatycznie nie zgadzały się ciągi liczb z tym, co znajdujemy w Biblii Ptockiej. Potwierdzają to kanony X, w których znajdujemy miejsca własne poszczególnych ewangelistów. Tam takich błędów jest najmniej, wtedy też zgodność z kanonami z Biblii Płockiej jest bardzo duża a rozbieżności nieliczne. Pytanie zasadnicze, które trzeba postawić w tym miejscu jest następujące: kto spisywał od kogo? Jeśli kanony Euzebiusza w Ewangeliarzu Anastazji są zależne od tych z Biblii Płockiej a ta ostatnia była już w Płocku w 1148 roku, co potwierdza zapis o cudzie dokonany na karcie 239v, to mogłoby oznaczać, że Ewangeliarz powstał również przed 1148 rokiem. Zakładając oczywiście, że kanony w Biblii Płockiej również już wtedy, czyli w 1148 roku w niej były i nie zostały dołączone później. Takiej pewności jednak nie mamy. Dalej, jeśli śmierć księżnej Anastazji miała miejsce w 1148 roku, a Ewangeliarz powstał po jej śmierci, to nasze kanony zostałyby przepisane z Biblii Płockiej później, czyli ok. 1150 roku lub nawet później, jeśli przesunie się rok śmierci księżnej na 1158 rok. Bardzo trudno jest rozstrzygnąć kwestie wzajemnej zależności pomiędzy tymi dwoma kodeksami tylko na bazie tak wąskiego materiału, jakim są kanony Euzebiusza i trzeba mieć nadzieję, że przyszłe badania nad tekstami w nich zawartymi pozwolą odpowiedzieć na to pytanie. Nie ulega natomiast wątpliwości, że istnieje ścisła zależność pomiędzy kanonami Euzebiusza z Biblii Płockiej a tymi z Ewangeliarza Anastazji. Jeśli kanony z Biblii Płockiej nie powstały w kraju Mozy, ale na miejscu w Płocku i zostały do niej dołączone, to również te z Ewangeliarza Anastazji zostałyby wykonane na miejscu. A ponieważ stanowią one integralną część kodeksu, gdyż pojawiają się po Prephatio św. Hieronima do czterech Ewangelii, następnie jego Prologus, Argumentum i Capitula, więc wiele wskazuje na to, że również Ewangeliarz Anastazji powstałby w lokalnym płockim skryptorium. Zaproponowana tutaj konkluzja jest oczywiście wstępną hipotezą i domaga się dalszych badań nad tymi kodeksami i tekstami biblijnymi, które przekazują.

\section{The Canons of Eusebius on Evangelarium Anastasiae of XII century Summary}

The article publishes for the first time the famous Canons of Eusebius of Cesarea transmitted in medieval codex called Evangelarium Anastasiae. The copmarison between the Canons of Eusebius transmitted in Evangelarium Anastasiae and in the famous Bible of Plock confirm the strict dependance between those two codexes. Thanks to two notes on the miracles which took place in the cathedral of Płock in 1148 and have been described in the Bible of Płock we know that the Bible should have been in Płock in this time, so it seems reasonable to suppose that also Evangelarium Anastasiae would have been transcribed in the local scriptorium in the middle of XII century.

Keywords: the princess Anastasia, biblical codex, medieval, Płock

Nota o Autorze: ks. dr hab. Leszek Misiarczyk, prof. UKSW. Pracuje na Wydziale Nauk Historycznych i Społecznych UKSW w Warszawie. 